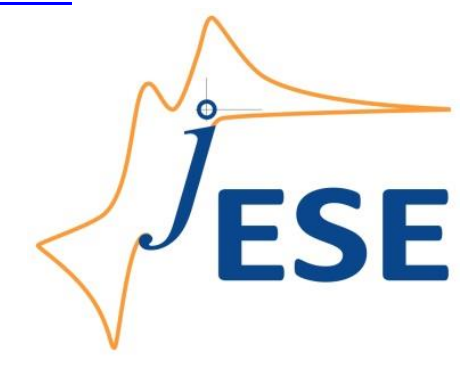

Open Access : : ISSN 1847-9286

www.jESE-online.org

Original scientific paper

\title{
Construction of new sensors with copper and cobalt comple- xes anchored on organofunctionalized silica and their use for electrocatalytic oxidation of reagents of biological interest
}

\author{
Marco A. G. Benetti, Denise I. Soares, Giovanna G. Alves, Eduardo D. A. Pinto and \\ Angélica M. Lazarin ${ }^{凶}$ \\ Departamento de Química, Universidade Estadual de Maringá, Av. Colombo, 5790, 87020-900 \\ Maringá, PR, Brazil \\ Corresponding author: $₫$ amlazarin2@uem.br; Tel.: +55 4432633241; Fax: +55 4430311011 \\ eceived: September 1, 2021; Accepted: February 14, 2022; Published: February 24, 2022
}

\begin{abstract}
This work describes the development and application of chemically modified carbon paste electrode (CMCPE) with metal ion complexes of transition metals Co(II) and $\mathrm{CU}$ (II) anchored on functionalized silica (SF). The prepared CMCPE was used for the determination of dopamine (DA) in the presence of pyridoxine $\left(V B_{6}\right)$ in commercially available pharmaceutical formulation, without any treatment of samples. The CMCPEs were built by incorporating graphite and functionalized silica and complexes of metal ions ( $\mathrm{Cu}$ and $\mathrm{Co}$ ) anchored by nitrogen groups on the silica surface. The electrochemical analysis was performed by cyclic voltammetry, while a drug analyzed in the present study was Revivan ampoules (DA determination).
\end{abstract}

Keywords

Chemically modified carbon electrode; functionalized silica; metal complexes; dopamine, vitamin $\mathrm{B}_{6}$, cyclic voltammetry

\section{Introduction}

In many studies detected in the literature associated with the preparing of chemically modified silica, particular regard has been put to modifying materials containing transition metal ions that create supported complexes on the silica surface. Such materials are used to construct chemically modified electrodes (CME), which are usually linked with electroanalysis and eletrocatalysis [1-3].

Due to the mechanical rigidity, chemical inertia and large surface area, chemically modified silica gel has also been used as a stationary phase for high-performance liquid chromatography [4], for immobilizing enzymes [5], catalysts [6] and as an adsorbent of metal ions in aqueous solution and not aqueous $[7,8]$. 
The present investigation describes the development and application of chemically modified carbon paste electrodes (CMCPE) with metal ion complexes of transition metals Co(II) and $\mathrm{Cu}$ (II) anchored on the functionalized silica, for the determination of dopamine (DA) in the presence of pyridoxine $\left(\mathrm{VB}_{6}\right)$ in commercially available pharmaceutical formulation, without any sample treatment. The cyclic voltammetry technique was used, and the drug analyzed in the present study is Revivan drug ampoules (DA determination).

It must be added that $\mathrm{VB}_{6}$ plays an important role in neurotransmitters synthesis, such as $\mathrm{DA}$ synthesis, and also participates in amino acid degradation reactions [9]. DA is an important neurotransmitter in the central nervous system (CNS) of mammals, having a concentration in extracellular fluid lower than that of ascorbic acid (AA) [10]. The voltammetric response with vitreous carbon electrode for dopamine, therefore, suffers the interference of ascorbic acid, which coexists in vivo in extracellular fluid of basic central nervous system, as anions in high concentration, and it has an oxidation potential close to dopamine (lower concentration) [11].

\section{Experimental}

\section{Materials}

All solutions were prepared using Millipore Milli-Q water. All chemicals were of analytical reagent grade and used without further purification. Silica gel (Merck), 3-(2-aminoethyl)aminopropyl]trimethoxysilane (Synth), ethanol (Synth), m-aminobenzoic acid (Sigma), hydrochloric acid (Merck), sodium hydroxide (Synth), ethylenediaminetetraacetic acid (Synth), copper chloride (Merck), and cobalt chloride (Merck) were used for all preparations. Graphite powder (1-2 mm particle size, Aldrich) and mineral oil (Aldrich) of high purity were used for the preparation of carbon paste. The supporting electrolyte used for all experiments was $0.10 \mathrm{~mol} \mathrm{dm}^{-3}$ phosphate buffer solution (PBS). Pyridoxine (Merck) and dopamine (Sigma) were used as analytes.

\section{AETS modified agent coated on the silica gel surface}

Silica gel was degassed at $423 \mathrm{~K}$ under vacuum $\left(10^{-3} \mathrm{~atm}\right)$ for 8 hours. About $40 \mathrm{~g}$ of this material was mixed with $32.0 \mathrm{~cm}^{3}$ of [3-(2-aminoethyl)aminopropyl] trimethoxysilane dissolved in $350 \mathrm{~cm}^{3}$ of dry toluene. The mixture was kept under reflux, mechanical stirring and inert nitrogen atmosphere for 12 hours. The resulting silica was firstly washed and filtered with ethanol and ethyl ether, and then in a Sohxlet extractor for 24 hours with ethanol, and finally dried at $353 \mathrm{~K}$ under vacuum (333 K). The prepared solid was named SF-AETS.

\section{Modification of SF-AETS silica with MABA}

In $10 \mathrm{~g}$ of SF-AETS silica suspended in $50.0 \mathrm{~cm}^{3}$ of bidistilled ethanol, the reagent $\mathrm{m}$-aminobenzoic acid (MABA) was added. The mixture was refluxed under mechanical stirring for one hour, then filtered and washed with ethanol and anhydrous ethyl ether. The silica obtained was named SFAETS/MABA.

\section{Characterization}

The nitrogen amount in SF-AETS and SF-AETS/MABA samples was determined by nitrogen elemental analysis on Perkin-Elmer Analyzer 2400 series $\mathrm{H}$ CHNS/O device. Infrared spectra of samples were performed on Perkin-Elmer FTIR spectrophotometer, model 1600 , by using pressed $\mathrm{KBr}$ pellets in the $4000-400 \mathrm{~cm}^{-1}$ range with $4 \mathrm{~cm}^{-1}$ of resolution. Thermogravimetric curves were recorded using a DuPont model 1090 B apparatus, coupled to a model 951 thermobalance, by heating from room 
temperature to $1273 \mathrm{~K}$ at a heating rate of $0.16 \mathrm{~K} \mathrm{~s}^{-1}$ in argon flow of $1.67 \mathrm{~cm}^{3} \mathrm{~s}^{-1}$. The samples varied in weight from 15.0 to $30.0 \mathrm{mg}$.

\section{Adsorption isotherms}

Adsorption isotherms for $\mathrm{CuCl}_{2}$ and $\mathrm{CoCl}_{2}$ in ethanol solutions were determined with the use of the batch-wise method. A series of samples containing $100 \mathrm{mg}$ of SF-AETS/MABA was shaken for 3 hours as previously established, in an orbital bath with variable concentrations of each metal halide at a constant temperature of $298 \pm 1 \mathrm{~K}$. The concentration of metal ions in solution in equilibrium with solid phase was determined by direct titration with EDTA $\left(0.010 \mathrm{~mol} \mathrm{dm}^{-3}\right)$ using murexide as an indicator. The amount of cations adsorbed, $n_{\mathrm{f}}$, was determined by applying the equation: $n_{\mathrm{f}}=\left(n_{\mathrm{a}}-n_{\mathrm{s}}\right) / m$, where $\mathrm{m}$ is the adsorbent mass and $n_{\mathrm{a}}$ and $n_{\mathrm{s}}$ are initial and equilibrium amounts of metal in the solution phase in moles, respectively, $n_{f}$ is a measure of coverage degree in actual experimental conditions, defined according to:

$$
n_{\mathrm{f}}=\frac{n_{\mathrm{a}}-n_{\mathrm{s}}}{m}=\sum_{\mathrm{m}} \frac{C_{(\mathrm{SF}-\mathrm{AETS} / \mathrm{MABA})_{\mathrm{m}} \mathrm{MCl}}}{m}
$$

In eq. (1), the summation extends over all species on the surface. The maximum number of moles of the adsorbed complex, $n_{\mathrm{f}}{ }^{\max }$, is equal to the maximum value of $n_{\mathrm{f}}$ when the concentration of Co(II) and $\mathrm{Cu}(\mathrm{II})$ tends to infinity.

Adsorption of $\mathrm{Co}(\mathrm{II})$ and $\mathrm{CU}(\mathrm{II})$ held in solution depends on the selectivity coefficients of complexes constituted with the ligand immobilized on the surface. The formation of equilibrium of the complex $\mathrm{Co}(\mathrm{II})$ and $\mathrm{Cu}(\mathrm{II})$ with SF-AETS/MABA was examined by a Filippov model $[12,13]$.

The reaction of a metal $(\mathrm{M})$ complex formation at the surface can be expressed by the following equation:

$$
\mathrm{MX}_{\mathrm{z}}+\mathrm{nR} \leftrightarrow \mathrm{MR}_{\mathrm{n}} \mathrm{X}_{\mathrm{z}}
$$

where $z$ is the charge of the metallic ion, $X$ is an anion with unit charge and $R$ is linking group, electrically neutral, and fixed on the support surface.

In the equilibrium, the following relation is applied:

$$
\theta_{\mathrm{n}} /\left(1-\theta_{\mathrm{n}}\right)=\gamma_{\mathrm{n}} C
$$

where the fraction of SF-AETS/MABA bonded to metal is $\theta_{n}=\tilde{n} n_{f} / n_{0} n_{0}$ is the quantity of MABA immobilized on SF-AETS ( $\mathrm{mol} \mathrm{g}^{-1}$ ), $\tilde{n}$ is the number of ligands bonded to the metal, and $\gamma_{n}$ is the stability constant.

Substitution for $\theta_{\mathrm{n}}$ in eq. (3) results in the ending expression [14]:

$$
\frac{1}{n_{\mathrm{f}}}=\frac{\tilde{n}}{N Y_{\mathrm{n}} C}+\frac{\tilde{n}}{N}
$$

Considering that metallic ions $\mathrm{Cu}(\mathrm{II})$ and $\mathrm{Co}(\mathrm{II})$, when adsorbed on the surface (with a homogeneous covering ligands), form immobilized complexes with different ratios between them and are anchored at SF-AETS/MABA, the total concentration of immobilized ligand on the surface is equal to the sum of the concentrations of all species; $N$ is the degree of functionalization, $C$ is the concentration of the surface complex; $\tilde{n}$ is the average number of supported ligands bound to a metallic ion, defined as:

$$
\tilde{n}=\frac{C_{\mathrm{MRX}_{2}}+2 C_{\mathrm{MR}_{2} \mathrm{X}_{2}}+\ldots+\mathrm{m} C_{\mathrm{MR}_{\mathrm{m}} \mathrm{x}_{2}}}{n_{\mathrm{f}}}
$$

where $\mathrm{m}$ adsorbent mass and $\mathrm{R}$ is linking group. 
Eq. (4) can be re-written as

$$
\frac{1}{n_{\mathrm{f}}}=\frac{\tilde{n}}{N \Gamma_{n} C}+\frac{\tilde{n}}{N}
$$

where $\Gamma_{\mathrm{n}}$ is the selectivity coefficient, equal to $\sum_{m=1}^{\mathrm{n}} y_{m}$.

\section{Electrode preparation and electrochemical measurements}

Modified CMCPE was prepared by mixing $30 \mathrm{mg}$ of silica, $30 \mathrm{mg}$ of graphite and a drop of mineral oil $\left(2.0 \times 10^{-2} \mathrm{~cm}^{3}\right)$. The paste was placed into a cavity on the area of a platinum disk, fused to the end of a glass tube with $1 \mathrm{~mm}$ of inner diameter. This proportion was used because of a great response reached with a preliminary test after a detailed study of the paste composition.

Electrochemical measurements were carried out using CMCPE as the working electrode, $\mathrm{Ag} / \mathrm{AgCl}$ (sat. $\mathrm{KCl}$ ) as the reference electrode and a platinum wire as the counter electrode. Electrochemical properties were explored by means of cyclic voltammetry with a PAR 273A (EG\&G) potentiostatgalvanostat. All experiments were performed in $0.10 \mathrm{~mol} \mathrm{dm}^{-3} \mathrm{PBS}$, under a pure argon atmosphere, and the $\mathrm{pH}$ value of electrolyte solutions was adjusted to 7.0 by adding $\mathrm{HCl}$ or $\mathrm{NaOH}$ solutions. Different supporting electrolytes were tested as well.

\section{Results and discussion}

\section{Surface characterizations}

Silica gel functionalized (SF) with [3-(2-aminoethyl)aminopropyl]trimethoxysilane group (AETS) was obtained according to the following reaction:

$$
\begin{array}{ccc}
\mathrm{Si}(\mathrm{OH})_{3}+\left(\mathrm{CH}_{3} \mathrm{O}\right)_{3} \mathrm{Si}\left(\mathrm{CH}_{2}\right)_{3} \mathrm{NH}\left(\mathrm{CH}_{2}\right)_{2} \mathrm{NH}_{2} \rightarrow \mathrm{SiO}_{3} \mathrm{Si}\left(\mathrm{CH}_{2}\right)_{3} \mathrm{NH}\left(\mathrm{CH}_{2}\right)_{2} \mathrm{NH}_{2}+3 \mathrm{CH}_{3} \mathrm{OH} \\
\mathrm{SF} & \text { AETS } & \text { SF-AETS }
\end{array}
$$

For SF-AETS silica, the amounts of supported groups were set by nitrogen analysis using the method described in the experimental part. The functionalization efficiency was determined for (silane) groups as $0.91 \pm 0.01 \mathrm{mmol} \mathrm{g}^{-1}$ in SF-AETS based on the nitrogen content.

Further modification of SF-AETS with m-aminobenzoic acid into SF-AETS/MABA was reached by the following reaction:

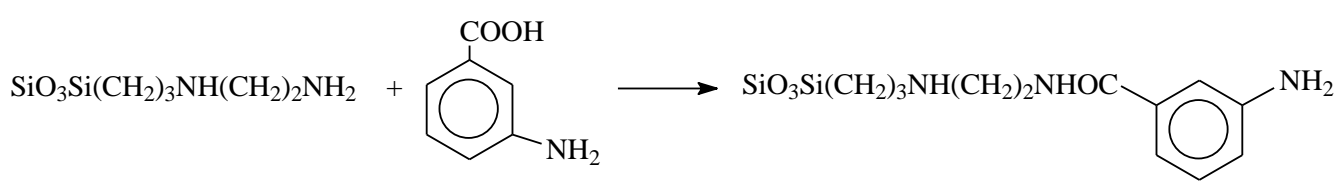

$$
\text { SF-AETS MABA SF-AETS/MABA }
$$

Subsequent coordination of metal ions at the surface of SF-AETS/MABA silica was obtained through reactions with metal chlorides, as shown below:

$$
\mathrm{SF} / \mathrm{AETS} / \mathrm{MABA}+\mathrm{M}(\mathrm{II}) \rightarrow \mathrm{SF} / \mathrm{AETS} / \mathrm{MABA} / \mathrm{M}(\mathrm{II})
$$

Figure 1 presents infrared spectra of SF, SF-AETS and SF-AETS/MABA silicas. The assignment of vibrational frequencies to pure silica (SF) and functionalized silica (SF-AETS) are listed in Table 1.

The appearance of new bands attributed to the stretch $\mathrm{CH}_{2}, \mathrm{NH}_{2}, \mathrm{CH}_{2} \mathrm{~N}$ and $\mathrm{SiCH}_{2}$ pointed to the effective functionalization of silica gel with AETS silylating agent on its surface. Infrared spectra of SF-AETS/MABA/Co(II) are shown in Figure 2. 


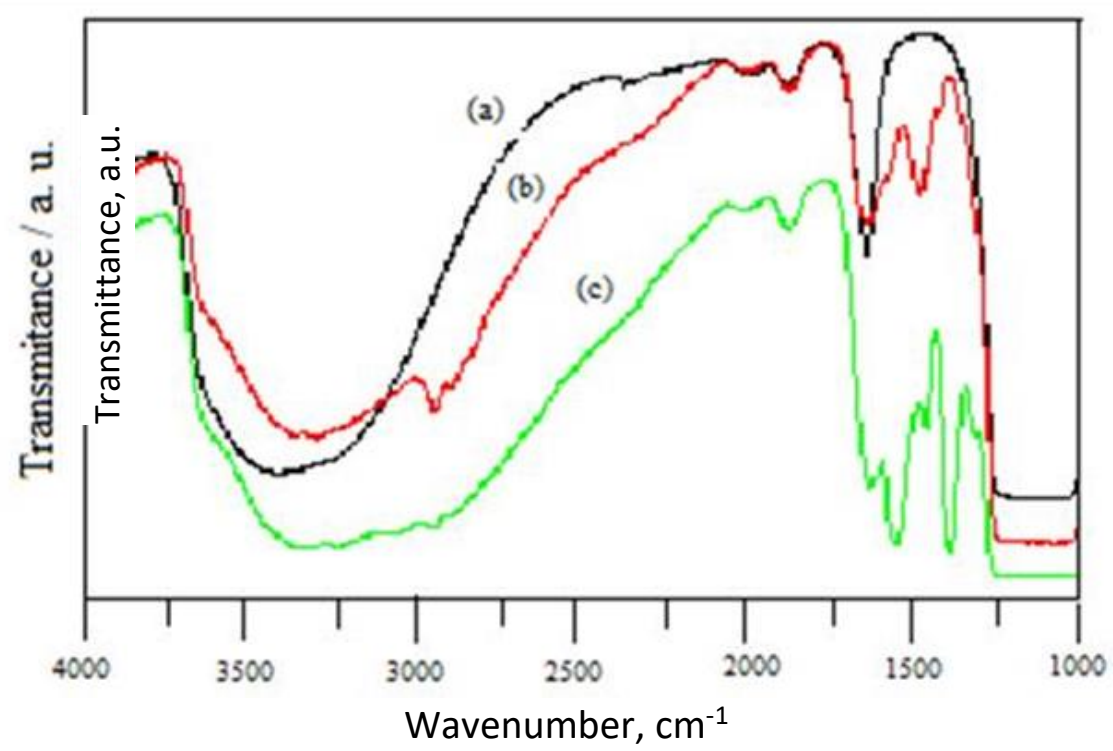

Figure 1. Infrared spectra of (a) SF, (b) SF-AETS and (c) SF-AETS/MABA

Table 1. Vibrational frequencies assigned for SF and SF-AETS silica

\begin{tabular}{ccc}
\hline$v_{\mathrm{SF}} / \mathrm{cm}^{-1}$ & $v_{\mathrm{SF}-\mathrm{AETS}} / \mathrm{cm}^{-1}$ & Assignment \\
\hline $3400(\mathrm{vs})$ & $3400(\mathrm{vs})$ & $v_{\mathrm{OH}}$ \\
\hline-- & $2940(\mathrm{w})$ & $v_{\mathrm{CH}_{2}}$ \\
\hline $1992(\mathrm{w})$ & $1995(\mathrm{w})$ & $*$ \\
\hline $1871(\mathrm{w})$ & $1870(\mathrm{w})$ & $*$ \\
\hline $1637(\mathrm{~s})$ & $1634(\mathrm{~s})$ & $\delta_{\mathrm{OH}}$ \\
\hline-- & -- & $\delta_{\mathrm{OH}} \delta_{\mathrm{NH}_{2}}$ \\
\hline-- & $1575(\mathrm{~m})$ & $\delta_{\mathrm{NH}_{2}}$ \\
\hline-- & -- & $v_{\mathrm{C}=\mathrm{c}}$ ring \\
\hline-- & $1480(\mathrm{~m})$ & $\delta_{\mathrm{CH}_{2} \mathrm{~N}}$ \\
\hline-- & $1418(\mathrm{~m})$ & $\delta_{\mathrm{SiH}_{2}}$ \\
\hline
\end{tabular}

* related to silica skeleton, $\mathrm{vs}=$ very strong band, $\mathrm{m}=$ mid band, $\mathrm{s}=$ short band, $\mathrm{w}=$ weak band

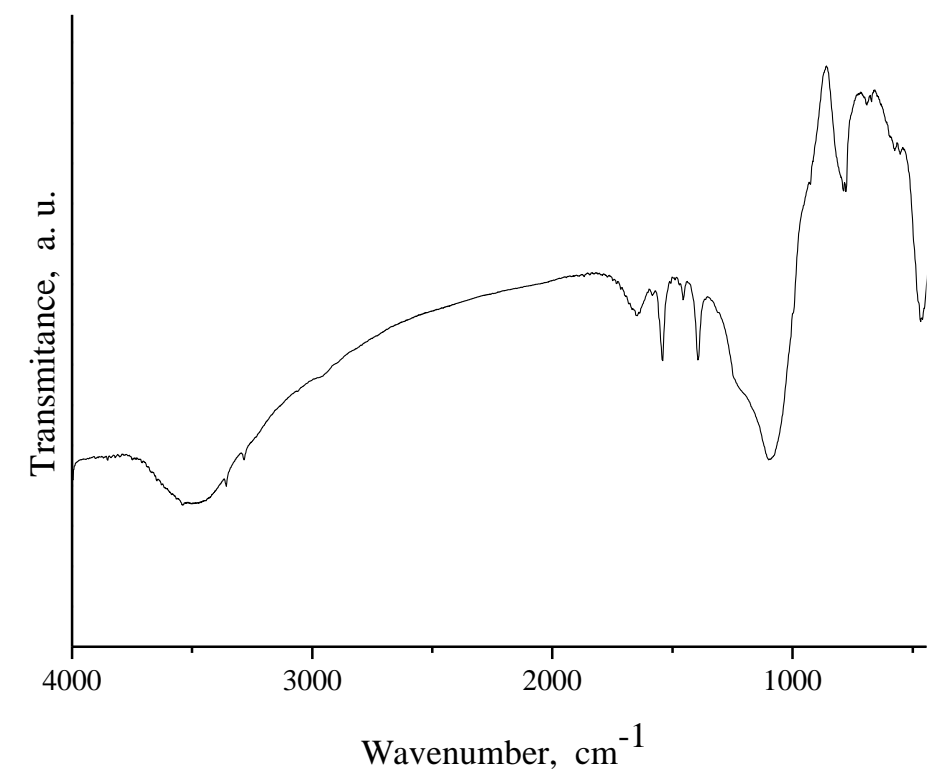

Figure 2. The infrared spectrum of SF-AETS/MABA/Co(II)

The assignments for SF-AETS/MABA and SF-AETS/MABA/Co(II) silicas are shown in Table 2. The comparison of infrared spectra in Figures 1 and 2 shows that in all spectra, a strong and wide band 
appears in the region of $3400 \mathrm{~cm}^{-1}$, attributed to $\mathrm{OH}$ stretches of water and silane groups, a band in the region of $1634 \mathrm{~cm}^{-1}$, which is characteristic of angular deformation of water [15], besides two bands close to $1900 \mathrm{~cm}^{-1}$ attributed to combinations of silica skeleton (Tables 1 and 2). Infrared spectra of SF-AETS/MABA silica with Co(II) ion anchored on its surface presented in Figure 2 showed a similar behavior (Table 2). The infrared spectra of the SF-AETS/MABA silica showed characteristic bands of amide bond $\left(1626+1605 \mathrm{~cm}^{-1}\right)\left(\delta_{\mathrm{HOH}}+\left(v_{\mathrm{C}=0}\right.\right.$, Band I of amide $)$ and $\left(1549 \mathrm{~cm}^{-1}\right)\left(\delta_{\mathrm{NH}}+v_{\mathrm{CN}}\right.$, Band II of amide), of the band in $\left(1386 \mathrm{~cm}^{-1}\right)\left(\delta_{\mathrm{CN}}\right.$ of and so on primary aromatic amine), showing that the successive change in surface SF-AETS silica actually occurred (Table 2).

Table 2. Vibrational frequencies assigned for SF-AETS/MABA and SF-AETS/MABA/Co(II).

\begin{tabular}{ccc}
\hline$\nu_{\text {SF-AETS/MABA }} / \mathrm{cm}^{-1}$ & $\nu_{\mathrm{SF}-\mathrm{AETS} / \mathrm{MABA} / \mathrm{CO}} / \mathrm{cm}^{-1}$ & Assignments \\
\hline $3400(\mathrm{vs})$ & $3400(\mathrm{vs})$ & $\nu_{\mathrm{OH}}$ \\
\hline $3343(\mathrm{vw})$ & $3253(\mathrm{vw})$ & $\nu_{\mathrm{NH}_{2}}$ \\
\hline $3226(\mathrm{vw})$ & & $\nu_{\mathrm{CH}}$ aromide \\
\hline $3067(\mathrm{vw})$ & $2940(\mathrm{vw})$ & $v_{\mathrm{CH}_{2}}$ \\
\hline $2940+2893(\mathrm{vw})$ & $2000(\mathrm{vw})$ & $\left({ }^{*}\right)$ \\
\hline $2000(\mathrm{vw})$ & $1871(\mathrm{w})$ & $\left.{ }^{*}\right)$ \\
\hline $1869(\mathrm{w})$ & $1631(\mathrm{~s})$ & $\delta_{\mathrm{HOH}}+\nu_{\mathrm{C}=\mathrm{O}}$ Band I of the amide \\
\hline $1626+1605(\mathrm{~s})$ & $1575(\mathrm{~m})+1492(\mathrm{vw})$ & $\delta_{\mathrm{CN}}$ Band II of the amide \\
\hline $1549(\mathrm{vs})$ & $1458(\mathrm{~m})$ & $\delta_{\mathrm{Si}-\mathrm{CH}}$ \\
\hline $1452(\mathrm{w})$ & $1407(\mathrm{~s})$ & $\nu_{\mathrm{CN}}$ primary aromatic amine \\
\hline- & $1387(\mathrm{~s})$ & $\delta_{\mathrm{NH}}+\nu_{\mathrm{CH}}$ Band III of secondary amide \\
\hline $1386(\mathrm{vs})$ & &
\end{tabular}

Thermogravimetric curves of pure silica (SF) and functionalized silica SF-AETS were obtained as described in the experimental part and shown in Figure 3. The SF and SF-AETS silica showed mass loss of 9.7 and $12.9 \%$, respectively. In examining these compounds, the following processes were detected: i) water molecules are lost from room temperature at near $500 \mathrm{~K}$, and ii) the functional groups are lost from 453 up to $813 \mathrm{~K}$.

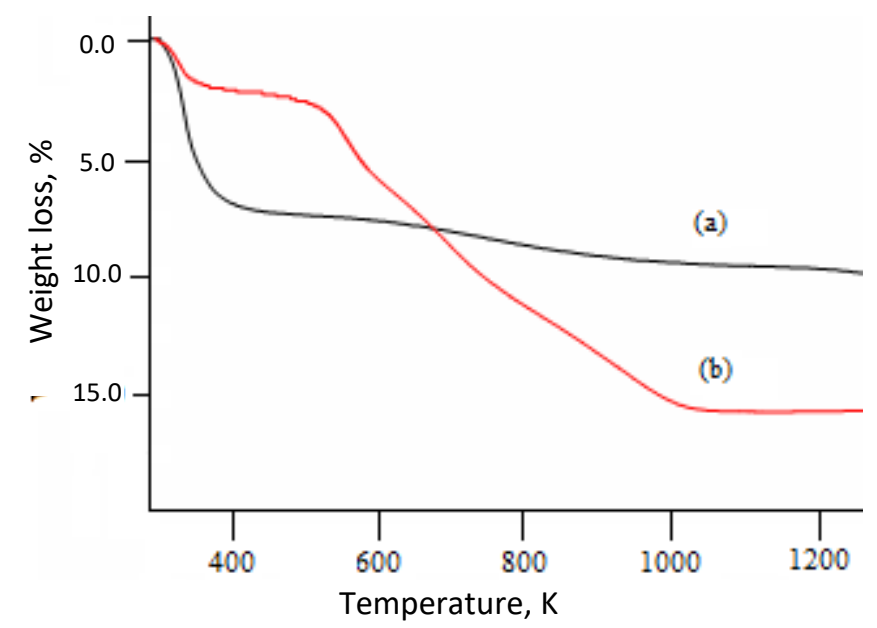

Figure 3. Thermogravimetric curves of (a) SF and (b) SF-AETS silica

The thermogravimetric curve of SF-AETS/MABA silica is shown in Figure 4 and presented a percentage of mass loss of $15.7 \%$ and the greatest mass loss occurring between 453 and $813 \mathrm{~K}$. 


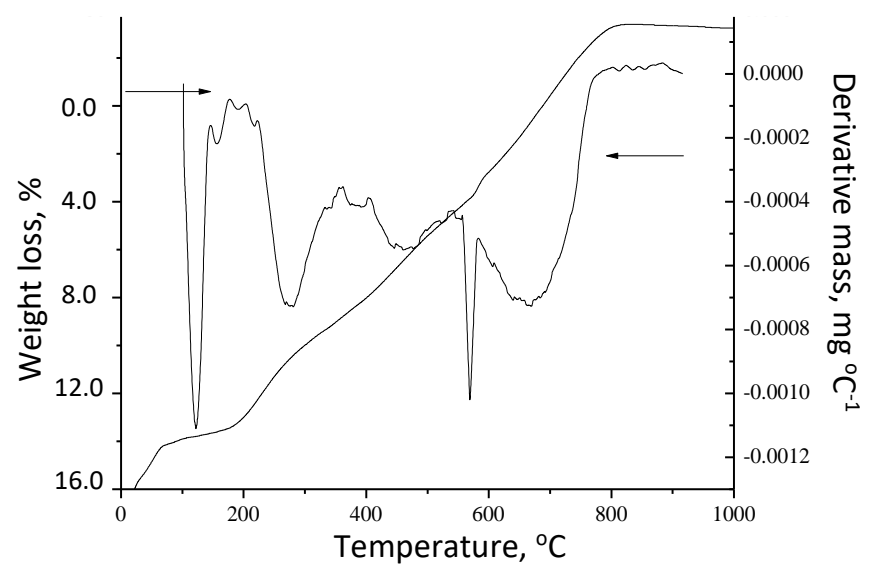

Figure 4. Thermogravimetric curves (integral and differential) of SF-AETS/MABA silica

\section{Adsorption of copper and cobalt}

The corresponding isotherms of metal ion adsorption from ethanol solutions of selected cations $\mathrm{CU}(\mathrm{II})$ and $\mathrm{Co}(\mathrm{II})$, at SF-AETS/MABA were also investigated. Early investigation showed that the original silica matrix does not adsorb these cations.

The solid adsorption capacity of metal halide on SF-AETS/MABA depends on the nature of the complex formed on the surface and the affinity of any particular ligand attached to the metal. Maximum adsorption capacity, $n_{\mathrm{f}}{ }^{\mathrm{max}}$, for $\mathrm{CuCl}_{2}$ and $\mathrm{CoCl}_{2}$, was 0.17 and $0.64 \mathrm{mmol} \mathrm{g}^{-1}$, respectively, indicating that cobalt binds more effectively than cooper to available basic centers. The average stability constant $(\Gamma)$ and the average number of ligands bonded and coordinated to the metallic ion

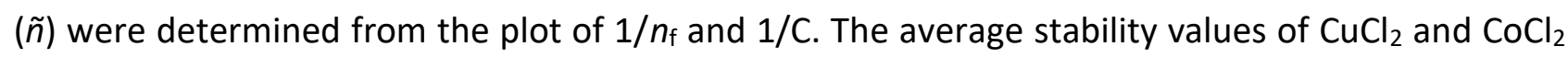

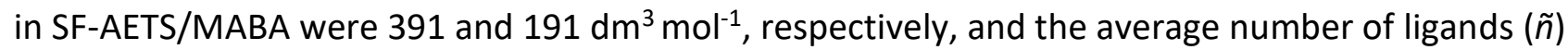
for SF-AETS/MABA was four to cooper and one to cobalt metallic ions. The values of calculated constants indicate the formation of stable complexes.

\section{Electrochemical studies}

Silica SF-AETS/MABA/Cu(II)

Voltammetry experiments using CMCPE modified with different silica materials were carried out. For the electrode modified with only SF-AETS/MABA, no current peaks were observed, while for CMCPE prepared with SF-AETS/MABA having complexed cooper (II) attached, some peaks were obtained. They can be observed in Figure 5, where stabilization of CMCPE/SF-AETS/ MABA/CU(II) in $0.10 \mathrm{~mol} \mathrm{dm}^{-3} \mathrm{PBS}, \mathrm{pH} 7.0$ was followed by cyclic voltammograms recorded consecutively at $20 \mathrm{mV} \mathrm{s}^{-1}$ in the potential range of -1.0 to $1.0 \mathrm{~V}(\mathrm{vs} . \mathrm{Ag} / \mathrm{AgCl})$ at $298 \mathrm{~K}$. In this potential range, a pair of peaks is observed in Figure 5, with almost reversible characteristics, $E_{1 / 2}=-0.11 \mathrm{~V}$ (where $E_{1 / 2}=$ $\left(E_{\mathrm{pa}}+E_{\mathrm{pc}}\right) / 2$ and $E_{\mathrm{pa}}$ and $E_{\mathrm{pc}}$ are anodic and cathodic peak potentials, respectively). These almost reversible peaks were assigned to the $\mathrm{Cu}(\mathrm{II}) / \mathrm{Cu}(\mathrm{I})$ redox pair, while the irreversible anodic peak at $E_{\mathrm{pa}}=0.90 \mathrm{~V}$ was assigned to the $\mathrm{Cu}(\mathrm{III}) / \mathrm{Cu}(\mathrm{II})$ redox pair.

Cyclic voltammograms of stabilized CMCPE/SF-AETS/MABA/Cu(II) electrode, recorded at different potential scan rates, are shown in Figure 6 . It is obvious that the value of the potential difference between anodic and cathodic peaks, $\Delta E_{\mathrm{p}}\left(\Delta E_{\mathrm{p}}=E_{\mathrm{pa}}-E_{\mathrm{pc}}\right)$, is increased at higher scan rates. This result reflects the kinetics of electron transfer on the electrode surface, which is not fast enough, as a consequence of having a matrix with considerable resistance. The graphs of anodic peak current as a function of the square root of scan rate and anodic peak current as a function of scanning rate (not shown here) presented linear behavior, which suggests a diffusion-controlled process [16,17]. 
Since it was shown earlier that electroactive species strongly adhere to the matrix, the mechanism may be explained by the transport of the ion of supporting electrolyte from the electrode surface for charge compensation $[18,19]$.

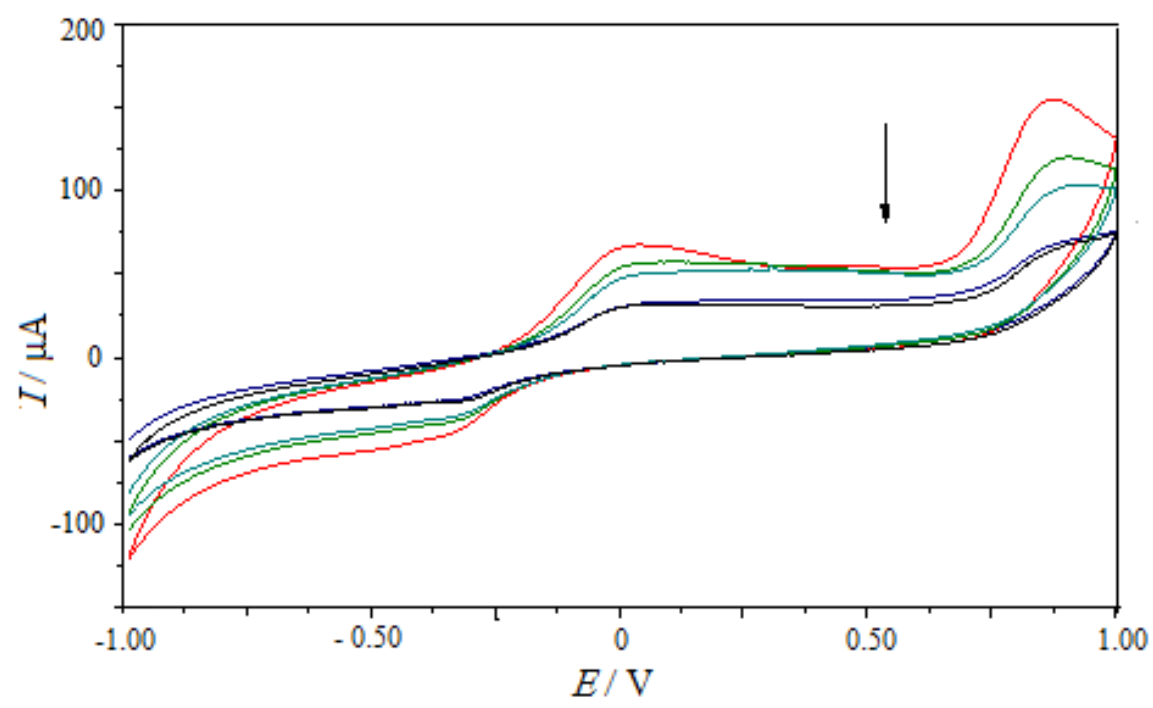

Figure 5. Cyclic voltammograms of CMCPE/SF-AETS/MABA/CU(II) electrode stabilization in $0.10 \mathrm{~mol} \mathrm{dm}^{-3} \mathrm{PBS}, \mathrm{pH} 7.0$, at $20 \mathrm{mVs}^{-1}$ and $298 \mathrm{~K}$

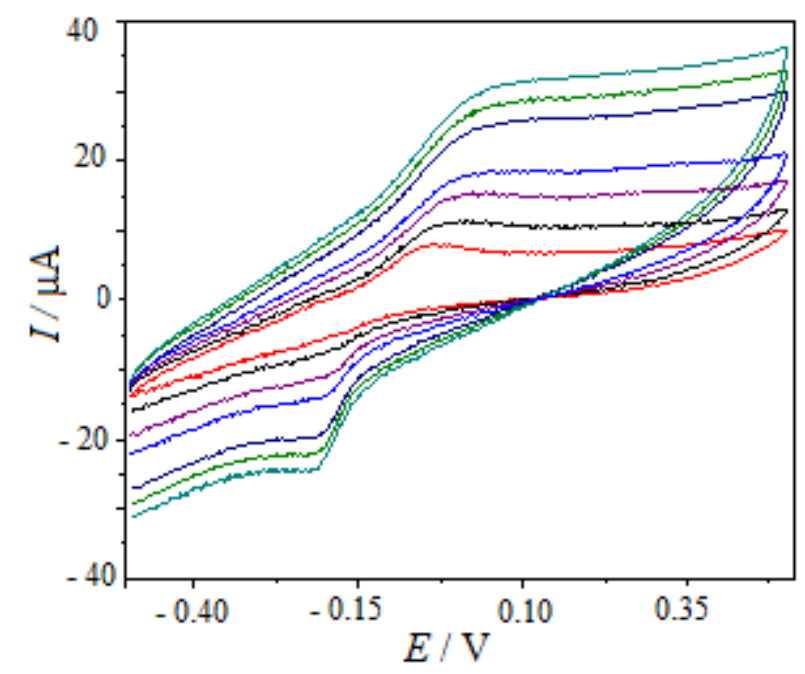

Figure 6. Cyclic voltammograms of CMCPE/SF-AETS/MABA/CU(II) electrode in $0.10 \mathrm{~mol} \mathrm{dm}-3 \mathrm{PBS}$ $\mathrm{pH} 7.0$, at $298 \mathrm{~K}$, as a function of the scan rate $\left(5,10,20,30,50\right.$ and $\left.60 \mathrm{mVs}^{-1}\right)$

The nature of supporting electrolyte that was changed by varying the cation and anion (phosphate buffer, $\mathrm{KCl}, \mathrm{NH}_{4} \mathrm{Cl}, \mathrm{NaNO}_{3}$ and $\mathrm{NH}_{4} \mathrm{NO}_{3}$ ) did not produce any significant influence on $E_{1 / 2}$. Such results suggested that these supporting electrolytes are not interacting with the matrix surface and produce no significant change of the midpoint potential [20].

With CMCPE/SF-AETS/MABA/CU(II) electrode, a preliminary study of oxidation of vitamin $\mathrm{B}_{6}$ was made by voltammetric measurements. Figure 7 shows electrochemical responses of CMCPE/SFAETS/MABA/Cu(II) without (curve a) and with $9.8 \times 10^{-4} \mathrm{~mol} \mathrm{dm}^{-3}$ of vitamin $\mathrm{B}_{6}$ (curve b). It is obvious that the anodic oxidation potential of $\mathrm{VB}_{6}$ is around $E_{\mathrm{pa}}=0.95 \mathrm{~V}$, as shown in Figure $7(\mathrm{~b})$.

Figure 8 shows the electrochemical behavior of CMCPE/SF-AETS/MABA/ Cu(II) electrode in PBS containing $0.30 \mathrm{~cm}^{3}$ of Revivan drug in the presence of vitamin $B_{6}\left(C_{V B 6}=9.8 \times 10^{-4} \mathrm{~mol} \mathrm{dm}^{-3}\right)$, and after successive additions of dopamine, in the concentration range of $9.6 \times 10^{-5}$ to $2.5 \times 10^{-4} \mathrm{~mol} \mathrm{dm}^{-3}$. 


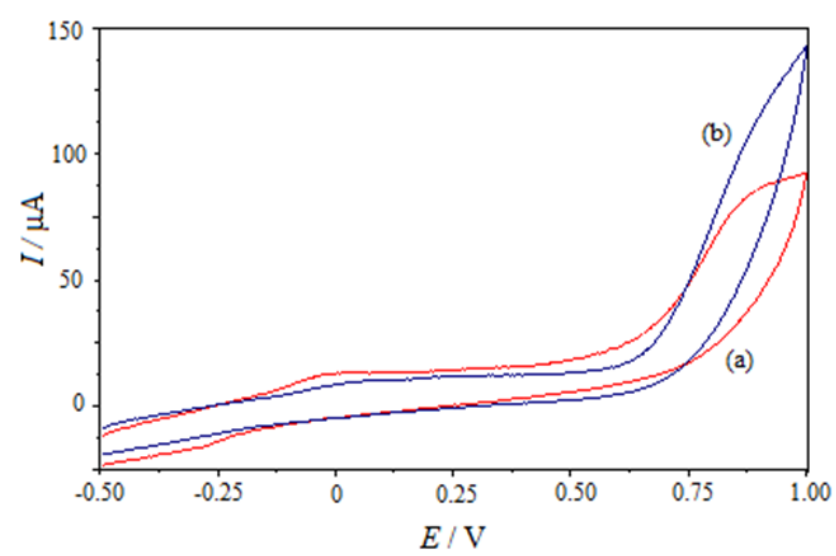

Figure 7. Electrochemical behavior of CMCPE/SF-AETS/MABA/CU(II) electrode in $0.10 \mathrm{~mol} \mathrm{dm^{-3 }} P B S$, pH 7.0, at $20 \mathrm{mV} \mathrm{s}^{-1}$ and $298 \mathrm{~K}$ : (a) without, and (b) with $9.8 \times 10^{-4} \mathrm{~mol} \mathrm{dm}^{-3}$ vitamin $B_{6}$

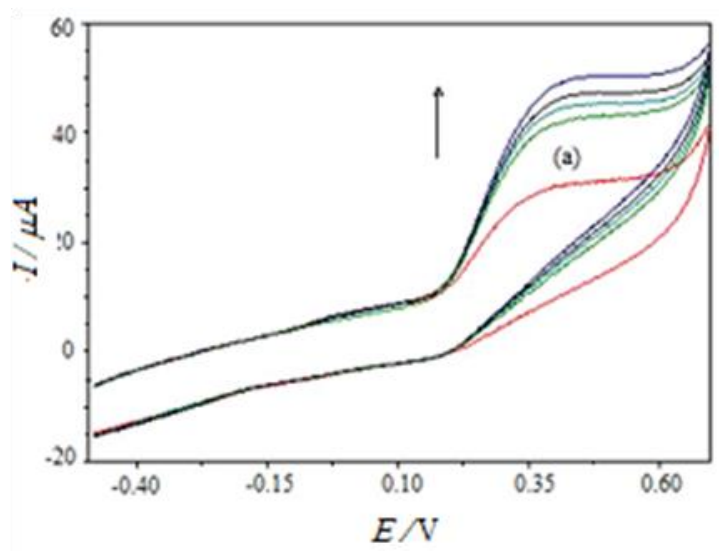

Figure 8. Dopamine determination in Revivan by the standard multiple addition method on the CMCPE/SF-AETS/MABA/Cu(II) electrode in $0.10 \mathrm{~mol} \mathrm{dm}^{-3} \mathrm{PBS}, \mathrm{pH} 7.0$, at $20 \mathrm{mV} \mathrm{s}^{-1}$ and $298 \mathrm{~K}$ :

(a) $0.30 \mathrm{~cm}^{3}$ of Revivan in the presence of $9.8 \times 10^{-4} \mathrm{~mol} \mathrm{dm}^{-3} \mathrm{VB} 6$ and after successive additions of dopamine $\left(9.6 \times 10^{-5}\right.$ to $\left.2.5 \times 10^{-4} \mathrm{~mol} \mathrm{dm}^{-3}\right)$

The oxidation potential of dopamine is at $E_{\mathrm{pa}}=0.39 \mathrm{~V}$, and anodic peak current graph versus dopamine concentration $\left(C_{\mathrm{DA}}=9.6 \times 10^{-5}\right.$ to $2.5 \times 10^{-4} \mathrm{~mol} \mathrm{dm}{ }^{-3}$ ) allowed the quantification of dopamine present in the drug. A linear correlation was observed between $I_{\mathrm{p}}$ and DA concentration, with a detection limit of $9.4 \times 10^{-5} \mathrm{~mol} \mathrm{dm}^{-3}$. The determined value in mol dm $\mathrm{dm}^{-3}$ was $5.1 \times 10^{-2}$, and after, this value was recalculated to $\mathrm{g} \mathrm{cm}^{-3}$. The value was found equal to $(4.9 \pm 0.3) \times 10^{-3} \mathrm{~g} \mathrm{~cm}^{-3}$ is in accordance with that supplied by the manufacturer.

The reproducibility of the electrode response to DA was also investigated by repetitive measurements. The results of 200 successive measurements showed a relative standard deviation of $1.03 \%$. Thus, the modified CMCPE/SF-AETS/MABA/Cu(II) electrode was found to be a very stable and highly reproducible electrode, appropriate for DA determination.

Silica SF-AETS/MABA/Co(II)

First, the stabilization of CMCPE/SF-AETS/MABA/Co(II) electrode was followed by recording consecutive CVs in $0.10 \mathrm{~mol} \mathrm{dm} \mathrm{m}^{-3} \mathrm{PBS}, \mathrm{pH} 7.0$ at $298 \mathrm{~K}$. CVs were carried out at $20 \mathrm{mV} \mathrm{s}^{-1}$ going from 1.0 to $-0.70 \mathrm{~V}$ (vs. $\mathrm{Ag} / \mathrm{AgCl}$ ) (cathodic scanning), and presented in Figure 9.

An almost reversible peak with $E_{1 / 2}=0.84 \mathrm{~V}$ can be assigned to the $\mathrm{Co}(\mathrm{III}) / \mathrm{Co}(\mathrm{II})$ redox pair. After the stability of the CMCPE/SF-AETS/MABA/Co(II) electrode was attained, it was used the study of oxidation of dopamine in the presence of vitamin $B_{6}$. Up to now, the electrochemical oxidation of vitamin $B_{6}$ has been mostly studied on carbon paste electrodes. 


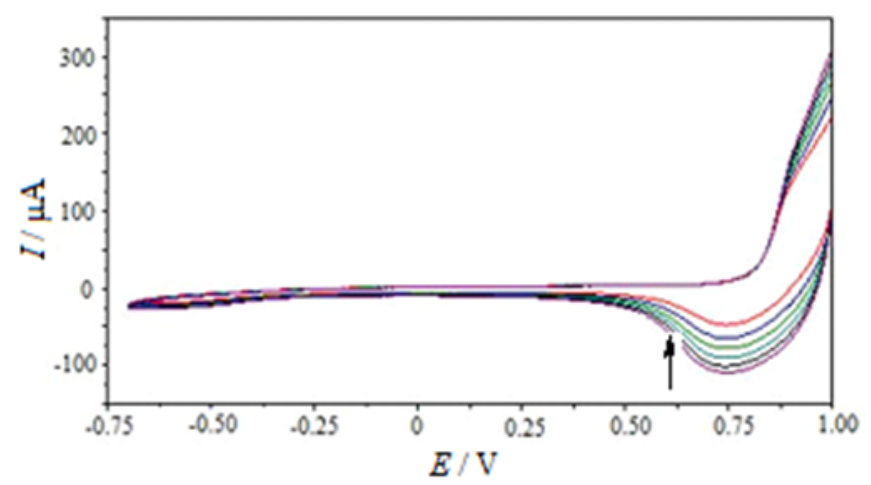

Figure 9. Cyclic voltammograms of CMCPE/SF-AETS/MABA/Co(II) electrode stabilization in $0.10 \mathrm{~mol} \mathrm{dm}^{-3} \mathrm{PBS}, \mathrm{pH} 7.0$, at $20 \mathrm{mVs}^{-1}$ and $298 \mathrm{~K}$

The reaction was supposed to involve the oxidation of pyridoxine (PYX) into pyridoxal derivative (PYO) [21]. The voltammetric response obtained with the CMCPE/SF-AETS/MABA/Co(II) after the successive additions of vitamin $B_{6}$ in the concentration range $9.9 \times 10^{-5}$ to $3.9 \times 10^{-4} \mathrm{~mol} \mathrm{dm}^{-3}$, however, did not present significant current variations (Figure 10). For this reason, CMCPE/SF$\mathrm{AETS} / \mathrm{MABA} / \mathrm{Co}$ (II) cannot be used for the electrochemical determination of vitamin $\mathrm{B}_{6}$ in the drug.

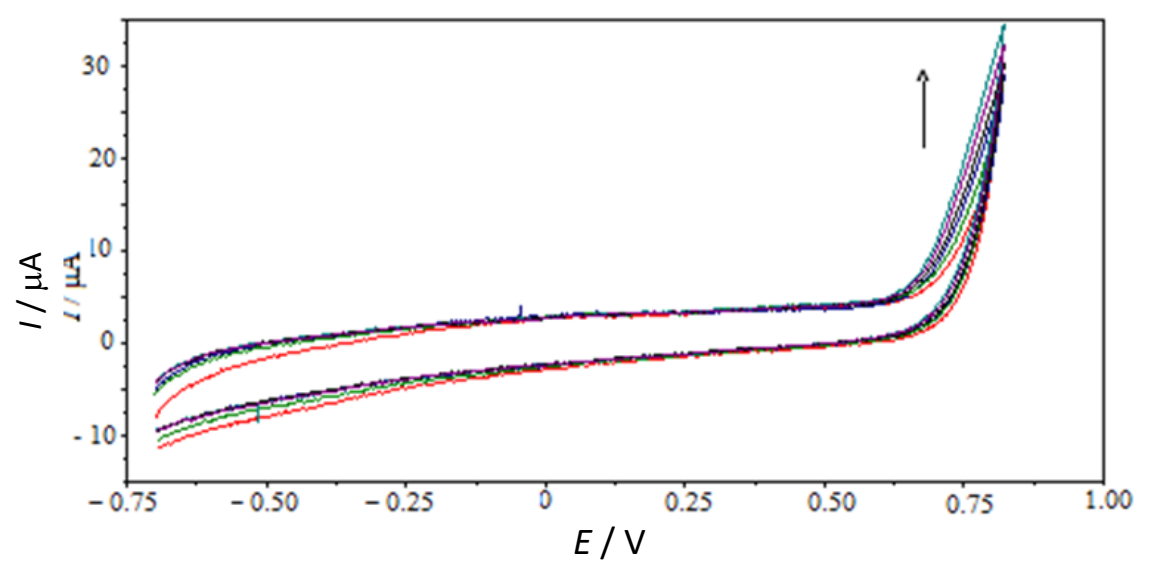

Figure 10. Electrochemical behavior of the CMCPE/SF-AETS/MABA/Co(II)electrode in $0.10 \mathrm{~mol} \mathrm{dm} \mathrm{m}^{-3} \mathrm{PBS}, \mathrm{pH} 7.0$, at $20 \mathrm{mV} \mathrm{s}^{-1}$ and $298 \mathrm{~K}$ without and with added vitamin $B_{6}$ in the concentration range of $9.9 \times 10^{-5}$ to $3.9 \times 10^{-4} \mathrm{~mol} \mathrm{dm}^{-3}$

Figure 11 shows the electrochemical behavior of CMCPE/SF-AETS/MABA/Co(II) electrode in $0.10 \mathrm{~mol} \mathrm{dm}^{-3} \mathrm{PBS}, \mathrm{pH} 7.0$, after dopamine additions of $5.0 \times 10^{-5}$ to $2.0 \times 10^{-4} \mathrm{~mol} \mathrm{dm}^{-3}$.

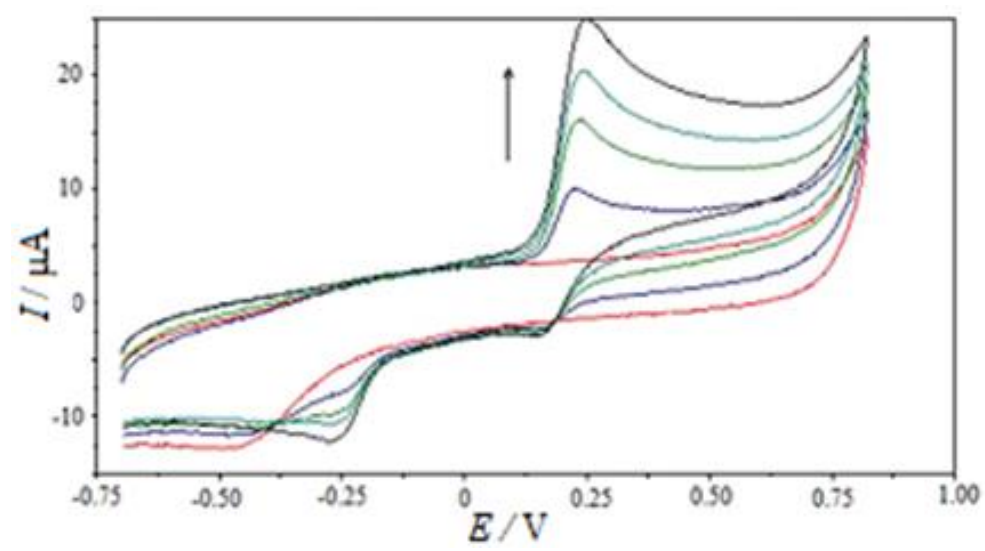

Figure 11. Electrochemical behavior of the CMCPE/SF-AETS/MABA/Co(II)electrode in $0.10 \mathrm{~mol} \mathrm{dm}^{-3} \mathrm{PBS}, \mathrm{pH} 7.0$, at $20 \mathrm{mV} \mathrm{s}^{-1}$ and $298 \mathrm{~K}$ without and with added DA in the concentration range of $5.0 \times 10^{-5}$ to $2.0 \times 10^{-4} \mathrm{~mol} \mathrm{dm}^{-3}$ 
Electrochemical behavior of CMCPE/SF-AETS/MABA/Co(II) electrode as a function of scanning rate in the presence of $2.0 \times 10^{-4} \mathrm{~mol} \mathrm{dm}^{-3}$ dopamine is presented in Figure 12 .

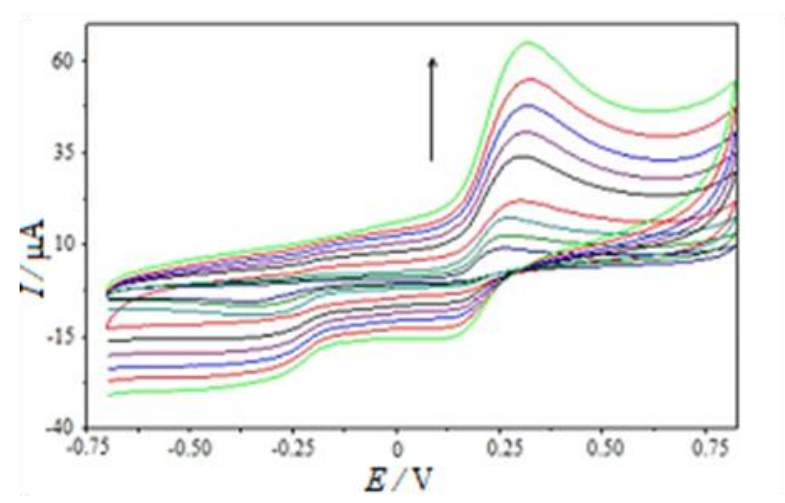

Figure 12. Electrochemical behavior of CMCPE/SF-AETS/MABA/Co(II) electrode in $0.10 \mathrm{~mol} \mathrm{dm}^{-3} \mathrm{PBS}, \mathrm{pH} 7.0,298 \mathrm{~K}$ and $2.0 \times 10^{-4} \mathrm{~mol} \mathrm{dm}^{-3} \mathrm{DA}$ at different scan rates $\left(2,5,10,20,30,40,50,60,70 \mathrm{mV} \mathrm{s}^{-1}\right)$

The graph of anodic peak current for CMCPE/SF-AETS/MABA/Co(II) at the oxidation potential of dopamine $\left(E_{\mathrm{pa}}=0.250 \mathrm{~V}\right)$ against $v^{1 / 2}$ presented linear behavior with two slopes, one at high and the other at low scan rates [22].

The electroanalytical determination of dopamine in Revivan ampoules was executed with this CMCPE/SF-AETS/MABA/Co(II) electrode by the method of multiple pattern addition. Dopamine concentration was varied from $4.9 \times 10^{-5}$ to $1.93 \times 10^{-4} \mathrm{~mol} \mathrm{dm}^{-3}$ and the presence of $B_{6}$ vitamin $4.5 \times 10^{-5} \mathrm{~mol} \mathrm{dm}^{-3}$ did not show significant variation (Figure 13). A linear correlation is observed between peak current and dopamine concentration with a detection limit of $4.9 \times 10^{-5} \mathrm{~mol} \mathrm{dm}^{-3}$. The graph of anodic peak current versus dopamine concentration allowed the quantification of dopamine present in the drug. The determined value in $\mathrm{mol} \mathrm{dm}^{-3}$ was $8.9 \times 10^{-2}$, and after, this value was recalculated to $\mathrm{g} \mathrm{cm}^{-3}$. The value was found equal to $(4.8 \pm 0.3) \times 10^{-3} \mathrm{~g} \mathrm{~cm}^{-3}$, which coincides with that provided by the manufacturer $\left(5 \mathrm{mg} \mathrm{cm}^{-3}\right)$.

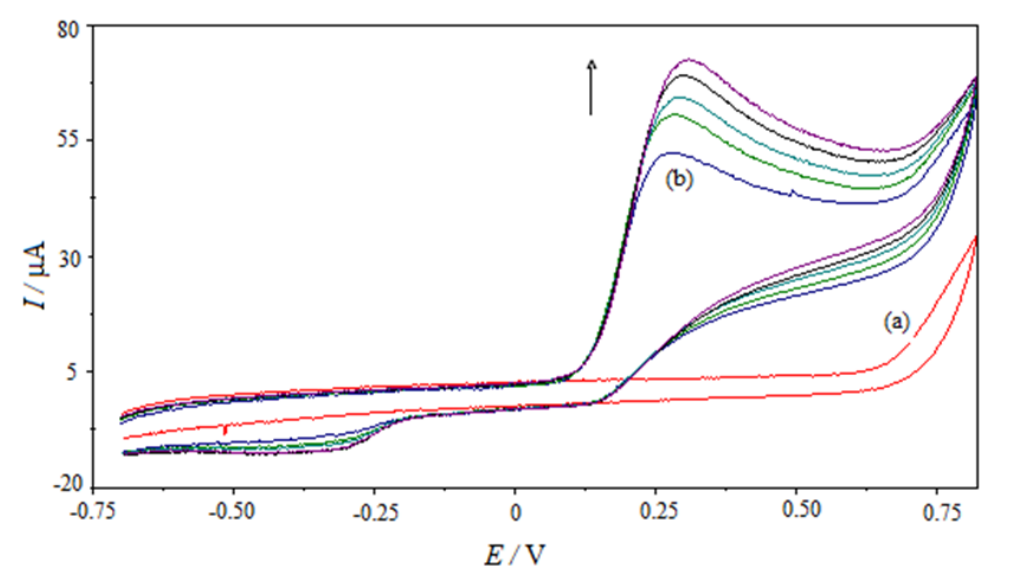

Figure 13. Determination of dopamine in Revivan by the multiple standard addition method at CMCPE/SF-AETS /MABA/Co(II) electrode in $0.1 \mathrm{~mol} \mathrm{dm}^{-3} \mathrm{PBS}, \mathrm{pH} 7$ at $20 \mathrm{mV} \mathrm{s}^{-1}$ and $298 \mathrm{~K}$. (a) cyclic voltammogram in the presence of $B_{6}$ vitamin $4.5 \times 10^{-5} \mathrm{~mol} \mathrm{dm}^{-3}$ (b) after addition of $0.50 \mathrm{~cm}^{3}$ of Revivan and successive additions of dopamine in the concentration range of $4.9 \times 10^{-5}$ to $1.93 \times 10^{-4}$ $\mathrm{mol} \mathrm{dm^{-3 }}$

The comparison of CMCPE/SF-AETS/MABA/Co(II) electrode response with that of glassy carbon electrode in the solution containing a mixture of vitamin $\mathrm{B}_{6}$ and dopamine is presented in Figure 14. Compared to glassy carbon, for the CMCPE modified with silica, there is no appearance of the 
oxidation peak of vitamin $\mathrm{B}_{6}$ in the studied potential range. Also, the current catalysis for dopamine oxidation is clearly presented for CMCPE/SF-AETS/MABA/Co(II) electrode, showing much greater sensitivity than is observed for the glassy carbon electrode.

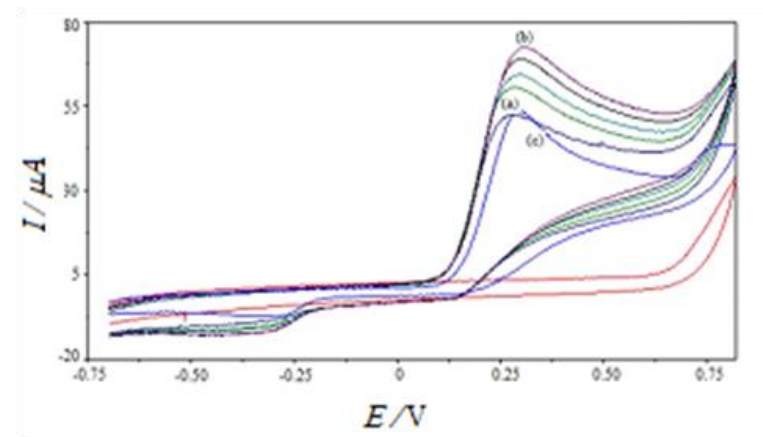

Figure 14. Comparison of ( $a$ and b) CMCPE/SF-AETS/MABA/Co(II) electrode and (c) glassy carbon electrode responses in $0.10 \mathrm{~mol} \mathrm{dm} \mathrm{m}^{-3} \mathrm{PBS}, \mathrm{pH} 7.0$, and $4.5 \times 10^{-5} \mathrm{~mol} \mathrm{dm}^{-3} \mathrm{VB}_{6}$ at $20 \mathrm{mV} \mathrm{s}^{-1}$, and $298 \mathrm{~K}$

after: (a) addition of $0.50 \mathrm{~cm}^{3}$ of Revivan; ( $b$ and c) addition of $1.93 \times 10^{-4} \mathrm{~mol} \mathrm{dm}^{-3}$ of dopamine

The performance of CMCPE/SF-AETS/MABA/Co(II) electrode over five months was followed by measurements of oxidation peak currents for dopamine in PBS on each consecutive day. This serves as an indicator of the stability of modified electrodes toward dopamine. The electrodes were used every day. The experimental results indicated that current responses showed a relative standard deviation of $2.0 \%$, suggesting that modified electrodes possess fine stability.

The reproducibility of electrodes was investigated. Repetitive measurements were performed in dopamine. The results of 200 successive measurements show a relative standard deviation of $1.03 \%$. Thus, the modified electrodes are found very stable, showing great reproducibility.

\section{Conclusions}

The enrichment of interfacial layer of silica gel by chemisorption, with interactions of covalent nature on its surface through the use of silylating agents with nucleophilic sites, favored the increased capacity of organofunctionalized silica to sequester metals, with complexes anchored on its surface. The analytical results obtained from the electrode containing $\mathrm{Cu}$ (II) and Co(II) complexes were very promising. The benefits to employ the suggested electrodes have been stated by our analytical processes, and its progress is easy. The electrodes did not present significant variation in response after five months of use, thus showing good chemical stability. These characteristics make this material very attractive for use as a sensor for dopamine determinations.

Acknowledgment: The authors are indebted Josué A. Da Silva for manuscript revision.

\section{References}

[1] X. Li, B. Wang, Y. Cao, S. Zhao, H. Wang, X. Feng, J. Zhou, X. Ma, Chemical Engineering 7(5) (2019) 4548-4563. https://doi.org/10.1021/acssuschemeng.8b05751

[2] S. K. Parida, S. Dash, S. Patel, B. K. Mishra, Advances in Colloid and Interface Science 121(1-3) (2006) 77-110. https://doi.org/10.1016/i.cis.2006.05.028

[3] K. Kalcher, Electroanalysis 2(6) (1990) 419-433. https://doi.org/10.1002/elan.1140020603

[4] A. M. Faria, C. H. Collins, I. C. S. F. Jardim, Journal of the Brazilian Chemical Society 20(8) (2009) 1385-1398. https://doi.org/10.1590/S0103-50532009000800002

[5] H. Maleki, A. T. Portugal, L. Durães, Journal of Non-Crystalline Solids 385 (2014) 55-74. http://dx.doi.org/10.1016/i.jnoncrysol.2013.10.017 
[6] R. F. Silva, W. L. Vasconcelos, Materials Research 2(3) (1999) 197-200. https://doi.org/10.1590/S1516-14391999000300014

[7] A. Mehdinia, S. Shegeftib F. Shemirani, Journal of the Brazilian Chemical Society 26(11) (2015) 249-2257. https://doi.org/10.5935/0103-5053.20150211

[8] M. G. Vieira, G. Souza, G. H. B. Aristides, L. V. Lopes, A. M. Lazarin, International Journal of Sensors and Sensor Networks 5(2) (2017) 27-33. https://doi.org/10.11648/i.ijssn.20170502.12

[9] [9] M. Parra, S. Stahl, H. Hellmann, Cells 7(7) (2018) 84. https://doi.org/10.3390/cells707$\underline{0084}$

[10] A. Mobed, M. Hasanzadeh, A. Ahmadalipour, A. Fakhari, Analytical Methods 12(4) (2020) 557-575. https://doi.org/10.1039/C9AY02390A

[11] C. A. Martínez-Huitle, M. Cerro-Lopez, M. A. Quiroz, Materials Research 12(4) (2009) 375384. https://doi.org/10.1590/S1516-14392009000400002

[12] A. P. Filippov, Theoretical and Experimental Chemistry 19 (1984) 427-433. https://doi.org/10.1007/bf00518093

[13] A. M. Lazarin, B. B. Cazula, Materials Chemistry and Physics 186(15) (2017) 470-477. https://doi.org/10.1016/i.matchemphys.2016.11.021

[14] R. Golbedaghi, F. Khajavi, Bulletin of the Chemical Society of Ethiopia 28(1) (2014) 1-8. https://doi.org/10.4314/bcse.v28i1.1

[15] A. Madejová, P. Komadel, Clays and Clay Minerals 49 (2001) 410-432. https://doi.org/10.1346/CCMN.2001.0490508

[16] A. J. Bard, L. R. Faulkner, Electrochemical Methods, Fundamentals and Applications, Wiley \& Sons, New York, 1980, 218.

[17] L. B. Panice, E. A. Oliveira, R. A. D. Molin Filho, D. P. Oliveira, A. M. Lazarin, E. I. S. Andreotti, R. L. Sernaglia, Y. Gushikem, Materials Science and Engineering B 188 (2014) 78-83. https://doi.org/10.1016/i.mseb.2014.06.010

[18] A. R. Harris, J. Zhang, R. W. Cattrall, A. M. Bond, Analytical Methods 5 (2013) 3840-3852. https://doi.org/10.1039/C3AY40769A

[19] M. Cuartero, R. G. Acres, R. De Marco, E. Bakker, G. A. Crespo, Analytical Chemistry 88(13) (2016) 6939-6946. https://doi.org/10.1021/acs.analchem.6b01800

[20] A. A. Hoffmann, S. L. P. Dias, E.V. Benvenutti, E. C. Lima, F. A. Pavan, J. R. Rodrigues, R. Scotti, E. S. Ribeiro, Y. Gushikem, Journal of the Brazilian Chemical Society 18(8) (2007) 1462-1472. https://doi.org/10.1590/S0103-50532007000800003

[21] J.-M. Zen, J.-C. Chen, A. S. Kumar, Tamkang Journal of Science and Engineering 5(4) (2002) 219-222. http://dx.doi.org/10.6180/jase.2002.5.4.03

[22] H. Yin, Y. Zhou, Q. Zhang, Q. Ma, Electrochimica Acta 56(6) (2011) 2748-2753. http://dx.doi.org/10.1016/i.electacta.2010.12.060

(C2022 by the authors; licensee IAPC, Zagreb, Croatia. This article is an open-access article distributed under the terms and conditions of the Creative Commons Attribution license (https://creativecommons.org/licenses/by/4.0/) 
